\title{
Development of cultured bovine embryos after exposure to high temperatures in the physiological range
}

\author{
R. M. Rivera and P. J. Hansen* \\ Department of Animal Sciences, University of Florida, PO Box 110920, \\ Gainesville, FL 32611-0920, USA
}

Embryonic development is inhibited by exposure of cultured embryos to high temperatures. However, culture temperatures used to demonstrate the effects of heat on development have been higher than the body temperatures experienced typically by heat-stressed cows. The aim of this study was to determine whether exposing bovine oocytes and embryos to temperatures characteristic of body temperatures of heat-stressed cows would affect embryonic development in vitro. The $\mathrm{CO}_{2}$ percentage of the gas phase was adjusted in all experiments to prevent $\mathrm{pH}$ changes in the medium caused by decreased solubility of $\mathrm{CO}_{2}$ at high temperatures. Fertilization of oocytes at $41.0^{\circ} \mathrm{C}$ reduced cleavage rate and the percentage of oocytes that became blastocysts compared with at $38.5^{\circ} \mathrm{C}$. There was no deleterious effect of fertilization at $40.0^{\circ} \mathrm{C}$. When putative zygotes and two-cell embryos were exposed to a range of temperatures from 38.5 to $41.0^{\circ} \mathrm{C}$ for $3,6,9$ or $12 \mathrm{~h}$, heat shock reduced the number that

\section{Introduction}

Heat stress can reduce fertility in cattle (Dutt, 1963; Dunlap and Vincent, 1971; Turner, 1982; Ealy et al., 1993; Ryan et al., 1993) and other species (Shah, 1956; Alliston and Ulberg, 1961; Tompkins et al., 1967). The mechanism by which heat stress causes embryonic mortality is multifactorial, as heat stress can alter several aspects of reproductive physiology, including blood flow to the reproductive tract (Roman-Ponce et al., 1978), ovarian steroid concentrations (Gwazdauskas et al., 1973; RomanPonce et al., 1981; Badinga et al., 1993; Trout et al., 1998) and patterns of follicular development (Badinga et al., 1993; Wolfenson et al., 1995). One possibility is that embryos cannot survive the increase in oviductal and uterine temperature that is coincident with heat stress. Culture of embryos at high temperatures has been reported to reduce embryonic development (Ulberg and Sheean, 1973; Edwards and Hansen, 1996, 1997). Similarly, increased culture temperatures can compromise oocyte function

*Correspondence

Email: hansen@animal.ufl.edu developed to the blastocyst stage but only after exposure to $41.0^{\circ} \mathrm{C}$ for 9 or $12 \mathrm{~h}$. In addition, it was tested whether low $\mathrm{O}_{2}$ tension would reduce the detrimental effects of heat shock. The deleterious effect of $41.0^{\circ} \mathrm{C}$ was not dependent upon oxygen content or the gas mixture used for culture $\left(5 \%\right.$ versus $\left.20.95 \% \mathrm{O}_{2}\right)$, indicating that the deleterious effects of heat shock did not depend upon a high $\mathrm{O}_{2}$ environment. In the final experiment, embryos were exposed to $24 \mathrm{~h}$ fluctuations in temperature designed to mimic the rectal temperatures of cows exposed to heat stress. Exposure of embryos to this pattern of temperatures starting after fertilization reduced development when embryos were exposed to this environment for 8 days but not when embryos were exposed for 1 day only. These findings indicate that embryonic development can be disrupted by a short-term severe or a prolonged mild heat shock and that the effects of heat shock are not artefacts of changes in $\mathrm{pH}$ or high oxygen tension.
(Lenz et al., 1983; Baumgartner and Chrisman, 1987; Edwards and Hansen, 1996) and fertilization rate (Ulberg and Burfening, 1967; Lenz et al., 1983).

Studies in cattle have demonstrated the deleterious effects of heat shock on cultured embryos at $41.0-43.0^{\circ} \mathrm{C}$ (Ealy et al., 1992; Ealy and Hansen, 1994; Edwards and Hansen, 1996, 1997). However, these experimental temperatures are higher than those generally experienced by heat-stressed cows with reduced fertility. For example, Dunlap and Vincent (1971) observed a reduction in fertility from $48 \%$ in control animals to $0 \%$ for heifers exposed to $32.2^{\circ} \mathrm{C}$ for $72 \mathrm{~h}$ immediately after mating; however, the mean rectal temperature of the heat-stressed heifers was $40.0^{\circ} \mathrm{C}$. Ryan et al. (1992) reported that a heat shock of $40.0^{\circ} \mathrm{C}$ actually increased the development of cultured bovine embryos.

Heat shock in culture differs from the situation in utero in several other respects. For example, increases in temperature in vitro cause decreased $\mathrm{CO}_{2}$ solubility in medium and an increase in medium $\mathrm{pH}$. This confounding of $\mathrm{pH}$ with heat shock has not been considered previously in experiments evaluating the effects of heat shock on embryos. Experiments on heat shock have also been performed in a gaseous environment in which $\mathrm{O}_{2}$ content is 
higher than in the oviduct $(8.7 \%$ in rabbits; Fischer and Bavister, 1993). As the effects of heat shock on embryonic development also involve free radicals (Ealy et al., 1992; Aréchiga et al., 1995), it is not known whether heat shock would affect embryonic development at oxygen environments similar to those found in vivo.

The aims of the present study were: (i) to determine whether exposing bovine oocytes and embryos to temperatures characteristic of the body temperatures of heatstressed cows would affect embryonic development in vitro; (ii) to determine whether culturing early bovine embryos in low oxygen concentrations would eliminate the adverse effects of heat shock on embryonic development; and (iii) to verify that the detrimental effects of heat shock were not due to changes in $\mathrm{pH}$ as a result of reduced solubility of $\mathrm{CO}_{2}$ at high temperatures.

\section{Materials and Methods}

\section{Materials}

FSH was Folltropin ${ }^{\circledR}-\mathrm{V}$ from Vetrepharm Canada Inc (London, Ontario) and was purchased from AgTech (Manhattan, KS). The culture media SP-TL, IVF-TL and Hepes-TL were prepared by Cell and Molecular Technologies Inc (Lavallete, NJ) using recipes described by Parrish et al. (1986). These media were used to prepare SP-TALP, Hepes-TALP and IVF-TALP as described by Parrish et al. (1986). The CR1aa medium was prepared as described by Rosenkrans et al. (1993). BSA fraction V, essentially fatty-acid free BSA fraction $V$ (EFAF-BSA) and all other chemicals were from Sigma (St Louis, MO).

\section{In vitro production of embryos}

Bovine ovaries were obtained from a local abattoir located at a travel distance of approximately $1.5 \mathrm{~h}$ from the laboratory. Ovaries were transported to the laboratory in $0.9 \%(\mathrm{w} / \mathrm{v}) \mathrm{NaCl}$ at room temperature. The ovaries were sliced and oocyte-cumulus complexes were collected into a beaker containing oocyte collection medium (TCM-199 with Hank's salts without phenol red and supplemented with $2 \%(\mathrm{v} / \mathrm{v})$ bovine steer serum (containing $2 U$ heparin $\left.\mathrm{ml}^{-1}\right), 100 \mathrm{iu}$ penicillin $\mathrm{ml}^{-1}$ and $0.1 \mathrm{mg}$ streptomycin $\mathrm{ml}^{-1}$ ). Cumulus-oocyte complexes (COCs) were cultured in $50 \mu \mathrm{l}$ microdrops of oocyte maturation medium (TCM199 with Earle's salts supplemented with $10 \%$ bovine steer serum 100 iu penicillin $\mathrm{ml}^{-1}, 0.01 \mathrm{mg}$ streptomycin $\mathrm{ml}^{-1}$, $2 \mu \mathrm{g}$ oestradiol $\mathrm{ml}^{-1}, 20 \mu \mathrm{g} \mathrm{FSH} \mathrm{ml} \mathrm{m}^{-1}$ and $0.2 \mathrm{mmol}$ sodium pyruvate $\mathrm{I}^{-1}$ ) in groups of 10 for 20-23 h. After maturation, the COCs were washed in Hepes-TALP and placed in groups of about 30 in $600 \mu$ IVF-TALP in four-well plates. Spermatozoa that had been purified by Percoll gradient centrifugation (Parrish et al., 1986) and suspended in SPTALP were added to the matured oocytes at a density of approximately $1 \times 10^{6}$ spermatozoa per well. Coculture of spermatozoa and COCs proceeded for 8-10 h, after which time the putative zygotes were denuded of cumulus cells by vortexing in a $2.0 \mathrm{ml}$ microcentrifuge tube containing $0.5 \mathrm{ml}$ Hepes-TALP for $5 \mathrm{~min}$. Putative zygotes were cultured in $50 \mu \mathrm{l}$ microdrops of CR1aa. On day 5 after insemination, $5 \mu \mathrm{l}$ fetal bovine serum was added to each culture drop.

All cultures were performed at $38.5^{\circ} \mathrm{C}$ in $5 \% \mathrm{CO}_{2}$ in humidified air unless specified otherwise. When cultures were performed at high temperatures, the $\mathrm{CO}_{2}$ percentage of the gas phase was adjusted to prevent $\mathrm{pH}$ changes in the medium caused by decreased solubility of $\mathrm{CO}_{2}$ at high temperatures. The $\mathrm{CO}_{2}$ percentage needed to maintain a $\mathrm{pH}$ of approximately 7.4 in the CR1 aa medium was determined experimentally for each temperature. These were $5.5,6.0,6.5$ and $7.0 \% \mathrm{CO}_{2}$ for 39.5, 40.0, 40.5 and $41.0^{\circ} \mathrm{C}$, respectively. The accuracy of the incubators was $\pm 0.2^{\circ} \mathrm{C}$ for one of the incubators and $0.1^{\circ} \mathrm{C}$ for two of the incubators. The temperatures of all incubators were calibrated routinely using mercury thermometers.

\section{Heat shock during fertilization}

Coculture of spermatozoa and COCs was performed for $8 \mathrm{~h}$ at $38.5,40.0$ or $41.0^{\circ} \mathrm{C}$. After fertilization, putative zygotes were cultured at $38.5^{\circ} \mathrm{C}$ for 8 days. The cleavage rate was determined on day 3 after insemination and development to the blastocyst stage was determined on day 8 after insemination. This experiment was replicated six times using a total of 179-180 oocytes per treatment.

\section{Heat shock at the one-cell stage}

After coculture of spermatozoa and COCs was complete (9 $\mathrm{h}$ after insemination), putative zygotes were cultured in $50 \mu \mathrm{l}$ microdrops in groups of $27-32$ at $38.5^{\circ} \mathrm{C}$ continuously or were exposed to 40.0 or $41.0^{\circ} \mathrm{C}$ for $3,6,9$ or $12 \mathrm{~h}$. After this time, all embryos were cultured at $38.5^{\circ} \mathrm{C}$ for the duration of the culture. Cleavage rate was determined on day 3 after insemination and development to the blastocyst stage was determined on day 8 after insemination. The experiment was replicated four times using 117-121 putative zygotes per treatment.

\section{Heat shock at the two-cell stage}

Two experiments were conducted. In both experiments, embryos at the two-cell stage were collected from culture drops at about $28 \mathrm{~h}$ after insemination and transferred to a new drop of CR1 aa medium (8-25 embryos per drop). For the first experiment, embryos were then cultured for 3, 6, 9 or $12 \mathrm{~h}$ at 40.0 or $41.0^{\circ} \mathrm{C}$ or were maintained at $38.5^{\circ} \mathrm{C}$. Furthermore, a group of embryos was left undisturbed in the original culture drops (two-cell embryos were not separated) to determine whether the handling itself would adversely affect development. After heat shock, the embryos were returned to $38.5^{\circ} \mathrm{C}$ for the duration of culture. Development to the blastocyst stage was determined on day 8 after insemination. Unlike most of the experiments, the type of BSA used to supplement CR1 aa was fraction V. 
The experiment was replicated five times with a total of 54-84 two-cell embryos per treatment.

The second experiment was conducted in a similar way except that heat shocks were at 39.5 and $40.5^{\circ} \mathrm{C}$. Furthermore, the CR1aa was supplemented with EFAFBSA. The experiment was replicated four times with a total of 52-68 embryos per treatment.

\section{Effect of type of BSA on response to heat shock}

The experiment was designed as a $2 \times 2$ factorial with two types of BSA (fraction $\mathrm{V}$ and EFAF) and two temperatures $\left(38.5\right.$ or $\left.41.0^{\circ} \mathrm{C}\right)$. Two-cell embryos were collected at about $28 \mathrm{~h}$ after insemination and placed in CR1aa supplemented with either EFAF-BSA or fraction $V$ BSA. Embryos were cultured continuously at $38.5^{\circ} \mathrm{C}$ or at $41.0^{\circ} \mathrm{C}$ for $12 \mathrm{~h}$ and $38.5^{\circ} \mathrm{C}$ thereafter. Development to the blastocyst stage was determined on day 8 after insemination. The experiment was replicated three times with a total of 57-58 embryos per treatment.

\section{Effect of oxygen concentration on response to heat shock}

This experiment was performed to determine whether the effects of heat shock in culture are exacerbated by high $\mathrm{O}_{2}$ environment. A chamber was constructed from a $115 \mathrm{ml}$ vacuum filter unit from Corning for regulation of the gaseous environment of cultured embryos. Tygon tubing $(3.2 \mathrm{~mm}$ i.d. $\times 6.4 \mathrm{~mm}$ o.d.) with a stopcock fastened to the end was attached to the hose connector and a 00 size rubber stopper was inserted into the pour spout. The cellulose nitrate membrane in the filter was punctured in several places to facilitate movement of gases. Culture plates were positioned gently on top of the membrane. The lid of the filter system was taped securely with scotch tape and parafilm was placed around the lid to make the chamber airtight. Gases were injected for $3 \mathrm{~min}$ through the pour spout from a hose connected to the gas cylinder while the stopcock was in the open position. Once injection of gases was complete, the rubber stopper was fastened to the pour spout and the stopcock was dialled to the closed position. A filter $(0.22 \mu \mathrm{m})$ was attached to the gas hose to prevent contamination during injection of gases. The chambers were airtight, as $\mathrm{pH}$ was maintained for $24 \mathrm{~h}$ in the presence of various gas mixtures.

The design was a $2 \times 2$ factorial with two $\mathrm{O}_{2}$ tensions (5 or $20.95 \%$ ) and two temperatures (38.5 and $41.0^{\circ} \mathrm{C}$ ). Embryos were collected at the two-cell stage and placed in fresh microdrops (14-27 embryos per drop). The culture plates were placed into airtight chambers. The chambers containing the embryos cultured at $38.5^{\circ} \mathrm{C}$ were injected with a mixture of gases containing high $(20.95 \%)$ or low (5\%) $\mathrm{O}_{2}$ with $5 \% \mathrm{CO}_{2}$ and a balance of $\mathrm{N}_{2}$. Chambers containing the embryos cultured at $41.0^{\circ} \mathrm{C}$ were injected with a similar mixture of gases except that $\mathrm{CO}_{2}$ was $7 \%$ to maintain a $\mathrm{pH}$ of about 7.4 and the $\mathrm{N}_{2}$ content was adjusted accordingly. After $12 \mathrm{~h}$ of culture, the plates were removed from the chambers and returned to incubators at $38.5^{\circ} \mathrm{C}$ and $5 \% \mathrm{CO}_{2}$ in air until day 8 after insemination. The experiment was replicated four times with a total of 80-107 embryos per treatment.

\section{Rectal temperatures of heat-stressed lactating dairy cows}

This experiment was performed as a prelude to determining the effects of culture temperatures characteristic of those experienced by heat-stressed cows on embryonic development. Animals used were primiparous $(n=8)$ or multiparous $(n=17)$ lactating Holsteins (day 50-150 of lactation except for one cow at day 266 of lactation) located in North Florida (Hague, Florida; 29' 46" N 82' $\left.25^{\prime \prime} \mathrm{W}\right)$. The cows were milked three times per day and received injections of bovine somatotrophin (Posilac; Monsanto, Chesterfield, MO) according to the manufacturer's recommendations. Milk yields on the day of recording ranged from 17.2 to $33.6 \mathrm{~kg} \mathrm{day}^{-1}$. The cows were kept in free-stall barns equipped with a cooling system using high-pressure foggers. On each of three separate days in August 1999, a group of nine cows was examined. Cows were chosen so that three cows were $>75 \%$ white in colour (white), three cows were $25-75 \%$ white (black and white) and three cows were $<25 \%$ white (black). Rectal temperatures were measured using mercury rectal thermometers (precision $=0.1^{\circ} \mathrm{C}$ ) and respiration rates were determined at $1 \mathrm{~h}$ intervals for $24 \mathrm{~h}$. In addition, relative humidity, dry bulb temperature and black globe temperature were recorded at $1 \mathrm{~h}$ intervals. For each replicate, a separate group of eight or nine cows in a different free-stall barn was used.

\section{Exposure of embryos to a pattern of temperatures similar to those experienced by heat-stressed cows}

Incubators were set at either $38.5,39.5$ or $40.5^{\circ} \mathrm{C}$. The heat shock treatment consisted of sequential exposure to $38.5^{\circ} \mathrm{C}$ for $5 \mathrm{~h}, 39.5^{\circ} \mathrm{C}$ for $5 \mathrm{~h}, 40.5^{\circ} \mathrm{C}$ for $5 \mathrm{~h}$ and $39.5^{\circ} \mathrm{C}$ for $9 \mathrm{~h}$. Given the limited number of incubators available, this pattern was found to mimic most closely the pattern of rectal temperatures experienced by cows in the previous experiment (see results). Putative zygotes were cultured continuously at $38.5^{\circ} \mathrm{C}$ (control group), heat shocked from day 0-1 after insemination (heat shock 0-1 group) or heat shocked on each day from day 0 to day 8 after insemination (heat shock 0-8). The experiment was replicated four times with 121-122 embryos per treatment.

\section{Statistical analysis}

For the embryo experiments, percentage cleavage and development was calculated for each microdrop of putative zygotes or embryos. Each experiment was replicated on several days with one or more microdrop per treatment on each day. Data were analysed by least-squares ANOVA using the PROC GLM procedures (SAS Institute, 1989). All 
main effects were considered fixed. Embryo number per drop was also included as a covariate for experiments with two-cell embryos where there was variation in the number of embryos per drop. Percentage data were transformed by arcsine transformation before analysis. The analysis of transformed data was used for probability values but least squares means \pm SEM are presented from analysis of untransformed data. In some experiments, the SAS option pdiff was used to compare the mean of each treatment with the mean of the control group. Orthogonal contrast was used to determine whether the effects of duration of heat shock followed a linear, quadratic or cubic pattern.

Rectal temperature data were analysed by least squares ANOVA. The mathematical model included the main effects of coat colour, replicate, cow (replicate $\times$ coat colour) and time. All interactions were included in the model. Cow was considered a random effect and other main effects were considered as fixed.

\section{Results}

\section{Effect of heat shock during fertilization}

Bovine oocytes fertilized at $41.0^{\circ} \mathrm{C}$ had lower $(P<0.01)$ cleavage rates than did oocytes fertilized at $38.5^{\circ} \mathrm{C}$ (Fig. 1a). The proportions of oocytes and cleaved embryos that developed to the blastocyst stage were also lower in oocytes fertilized at $41^{\circ} \mathrm{C}$ compared with those fertilized at $38.5^{\circ} \mathrm{C}(P<0.01)$ (Fig. 1b). A heat shock of $40.0^{\circ} \mathrm{C}$ during fertilization had no effect on cleavage rate and tended to increase the proportion of oocytes forming blastocysts compared with oocytes fertilized at $38.5^{\circ} \mathrm{C}$.

\section{Heat shock at the one-cell stage}

No reduction in cleavage rate or blastocyst formation was detected for one-cell embryos cultured at $40.0^{\circ} \mathrm{C}$ for $3,6,9$ or $12 \mathrm{~h}$, or $41.0^{\circ} \mathrm{C}$ for 3 or $6 \mathrm{~h}$. However, a heat shock of $41.0^{\circ} \mathrm{C}$ for $12 \mathrm{~h}$ reduced cleavage rate $(P<0.01)$ (Fig. 2a). Similarly, development to the blastocyst stage was affected adversely only by heat shocks of $41.0^{\circ} \mathrm{C}$ for 9 or $12 \mathrm{~h}(P<0.01$; Fig. $2 \mathrm{~b})$.

\section{Heat shock at the two-cell stage}

In the first part of this experiment, a heat shock of $40.0^{\circ} \mathrm{C}$ did not significantly reduce the percentage of two-cell embryos that developed into blastocysts by day 8 after insemination (Fig. 3a). In contrast, incubation at $41.0^{\circ} \mathrm{C}$ for 9 and $12 \mathrm{~h}$ significantly reduced the proportion of embryos that were blastocysts at day 8 after insemination $(P<0.01)$. In the second experiment, exposure to either 39.5 or $40.5^{\circ} \mathrm{C}$ did not reduce the rate of blastocyst formation (Fig. 3b). The proportion of embryos reaching the blastocyst stage was greater for the second experiment, in which the medium was supplemented with EFAF-BSA, than for the first experiment, in which the medium was supplemented with fraction $\mathrm{V}$ BSA. Accordingly, another
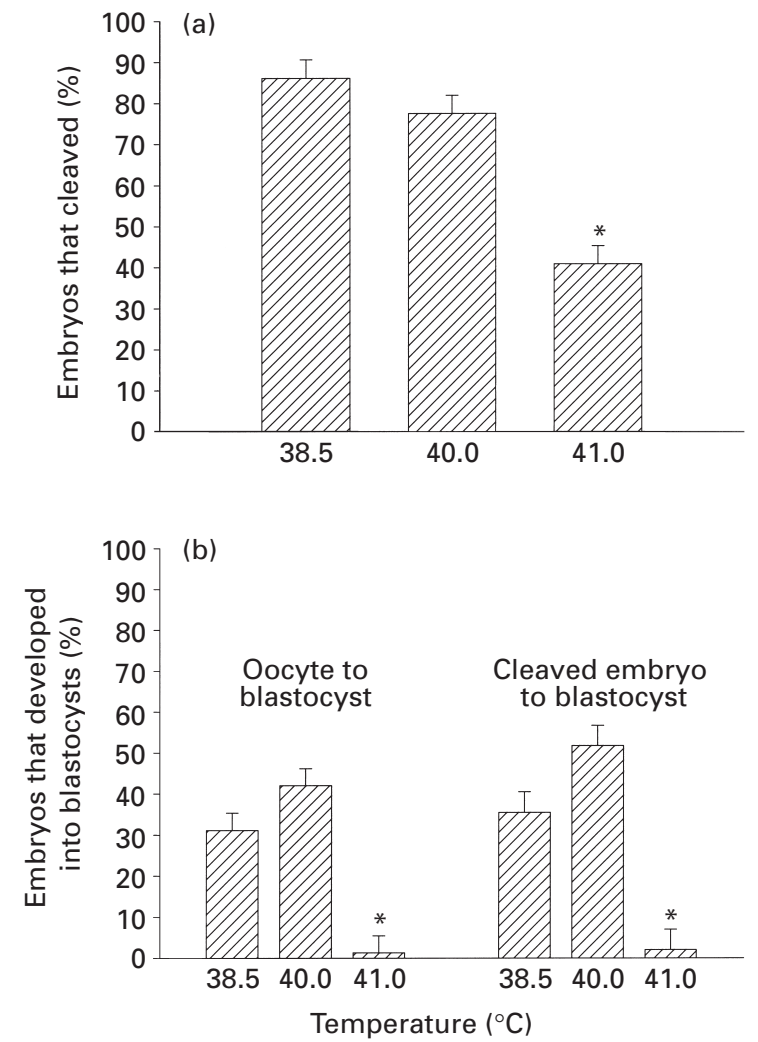

Fig. 1. Effect of temperature during fertilization on the percentage of oocytes that (a) cleaved and (b) developed into blastocysts on day 8 after insemination. Data are least squares means \pm SEM (mean of six replicates, each with 179-180 oocytes per treatment). Fertilization was for $8 \mathrm{~h}$ at $38.5,40.0$ or $41.0^{\circ} \mathrm{C}$. *Significantly different from control value $\left(38.5^{\circ} \mathrm{C}\right)(P<0.01)$.

experiment was performed to verify this effect of BSA type and to determine whether the BSA source would affect responses to heat shock (Fig. 4a). Two-cell embryos cultured at $38.5^{\circ} \mathrm{C}$ had a higher rate of blastocyst formation than did embryos exposed to $41.0^{\circ} \mathrm{C}$ for $12 \mathrm{~h}(P<0.02)$. In addition, the percentage of embryos that developed into blastocysts was higher $(P<0.01)$ for embryos cultured in CR1aa medium containing EFAF-BSA than for those cultured in CR1aa medium containing Fraction V. However, there was no temperature $\times$ BSA interaction, indicating that the effect of heat shock was similar for the two media.

\section{Effect of oxygen concentration on response to heat shock}

The two-cell embryos cultured at $38.5^{\circ} \mathrm{C}$ had a higher $(P<0.01)$ rate of blastocyst formation than did embryos exposed to a heat shock of $41.0^{\circ} \mathrm{C}$ for $12 \mathrm{~h}$ (Fig. $4 \mathrm{~b}$ ). Low $\mathrm{O}_{2}$ tended to increase the number of embryos that developed to the blastocyst stage, although the embryos were only in the presence of low $\mathrm{O}_{2}$ for $12 \mathrm{~h}$ at the two-cell stage. However, culturing two-cell embryos in low $\mathrm{O}_{2}$ tensions did not decrease the effect of heat shock on 

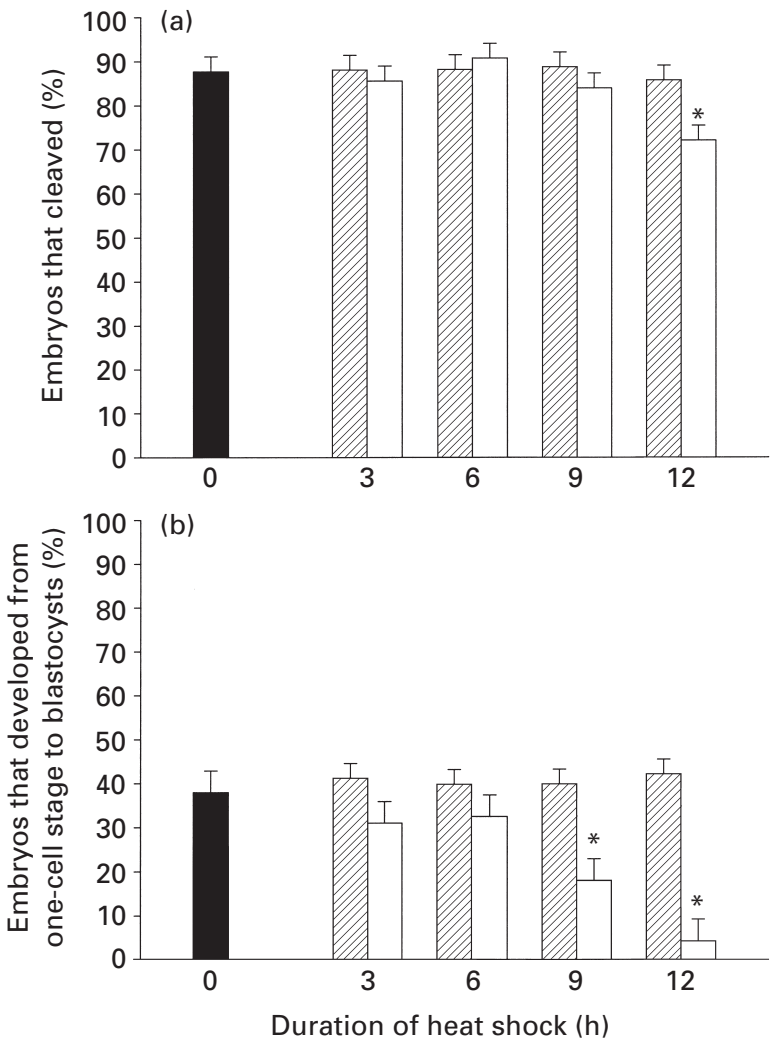

Fig. 2. Effect of heat shock (匹: $38.5^{\circ} \mathrm{C}$; $\square$ : $40.0^{\circ} \mathrm{C}$; and $\square: 41.0^{\circ} \mathrm{C}$ ) at the one-cell stage of development on the percentage of oocytes that (a) cleaved and (b) became blastocysts on day 8 after insemination. Data are least squares means \pm SEM (mean of four replicates, each with 117-121 oocytes per treatment). *Significantly different from control value $\left(38.5^{\circ} \mathrm{C}\right)(P<0.01)$.

embryonic development, as indicated by the lack of oxygen $\times$ temperature interaction. Heat shock reduced development from 53.5 to $27.0 \%$ at $20.95 \% \mathrm{O}_{2}$ and from 69.4 to $29.9 \%$ in $5 \% \mathrm{O}_{2}$.

\section{Rectal temperatures of heat-stressed lactating dairy cows}

The mean peak air temperatures and peak black globe temperatures on the days when the experiment was performed were 34.5 and $33.7^{\circ} \mathrm{C}$, respectively (Fig. 5a). Mean rectal temperatures ranged from $38.6^{\circ} \mathrm{C}(08: 00 \mathrm{~h})$ to $40.5^{\circ} \mathrm{C}(17: 00 \mathrm{~h})$ (Fig. 5b). Mean respiration rates ranged from 71.8 breaths $\min ^{-1}(08: 00 \mathrm{~h})$ to 105 breaths min $^{-1}$ (12:00 h; data not shown). Coat colour affected rectal temperatures of cows $(P<0.001)$, with predominantly white cows having lower rectal temperatures than predominantly black cows (Fig. 5b).

\section{Exposure of embryos to a pattern of temperatures similar to those experienced by heat-stressed cows}

The results of the previous experiment were used to design a pattern of culture temperatures that would mimic

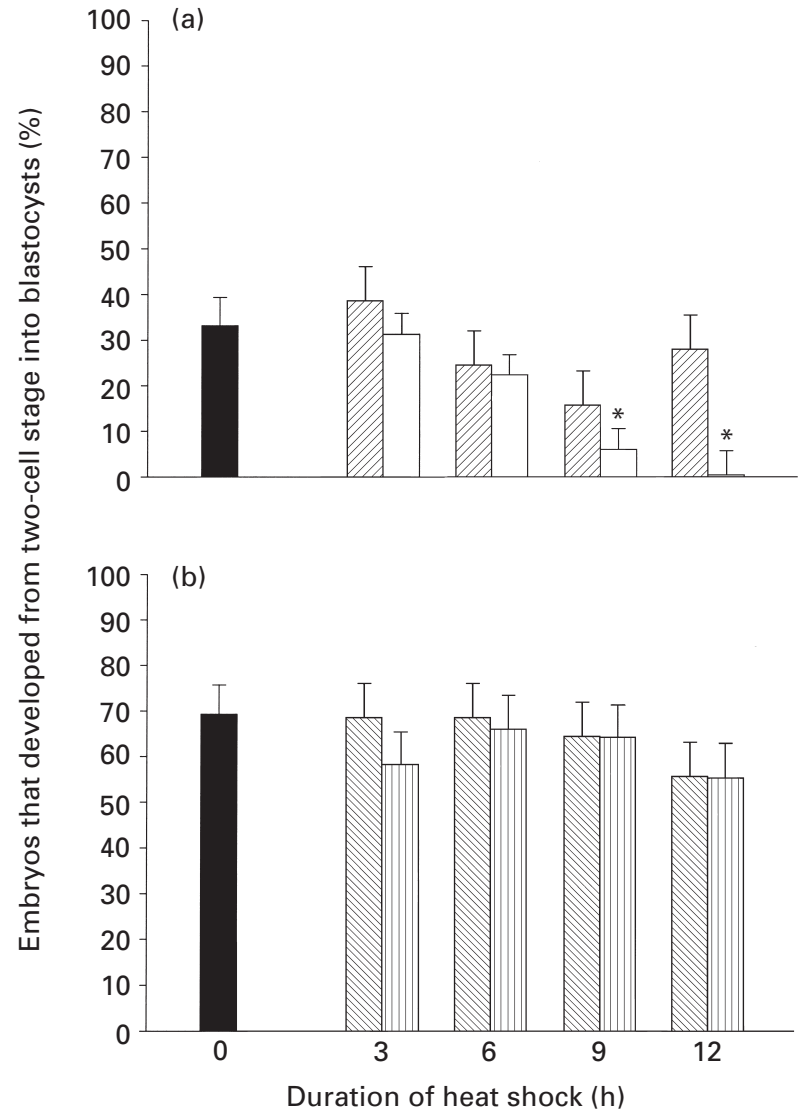

Fig. 3. Effect of heat shock at (a) 38.5 (回), 40.0 (四) and $41.0^{\circ} \mathrm{C}$ $(\square)$ and (b) $38.5(\mathbb{\square}), 39.5(\mathbb{\nabla})$ and $40.5^{\circ} \mathrm{C}(\square)$ at the two-cell stage of development on the percentage of two-cell embryos that became blastocysts on day 8 after insemination. Embryos were heat shocked for 3-12 h starting at about $28 \mathrm{~h}$ after insemination. Data are least squares means \pm SEM (mean of four replicates, each with 52-84 oocytes per treatment). There was a cubic effect $(P<0.1)$ of duration of heat shock at $40^{\circ} \mathrm{C}$. There was a linear effect $(P<0.001)$ of duration of heat shock at $41.0^{\circ} \mathrm{C}$. *Significantly different from control value (temperature $38.5^{\circ} \mathrm{C}$ ) $(P<0.01)$.

the $24 \mathrm{~h}$ variation in body temperatures. Applying heat shock in this pattern from 52 to $84 \mathrm{~h}$ after insemination did not affect embryonic development to the blastocyst stage (Fig. 6b). In contrast, application of this pattern of fluctuating temperatures for $192 \mathrm{~h}$ (day 0-8 after insemination) reduced development of embryos to the blastocyst stage $(P<0.05)$.

\section{Discussion}

The results of the present study indicate that embryonic development can be disrupted by heat shock of $41.0^{\circ} \mathrm{C}$ applied during fertilization and at the one- and two-cell stages of development. Furthermore, exposing early embryos to temperatures similar to those experienced by heat-stressed dairy cows can reduce development to the blastocyst stage. Thus, under certain circumstances, 


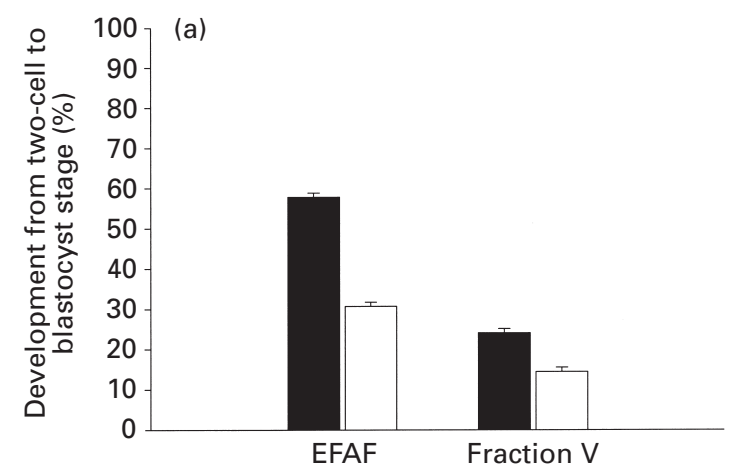

Type of BSA

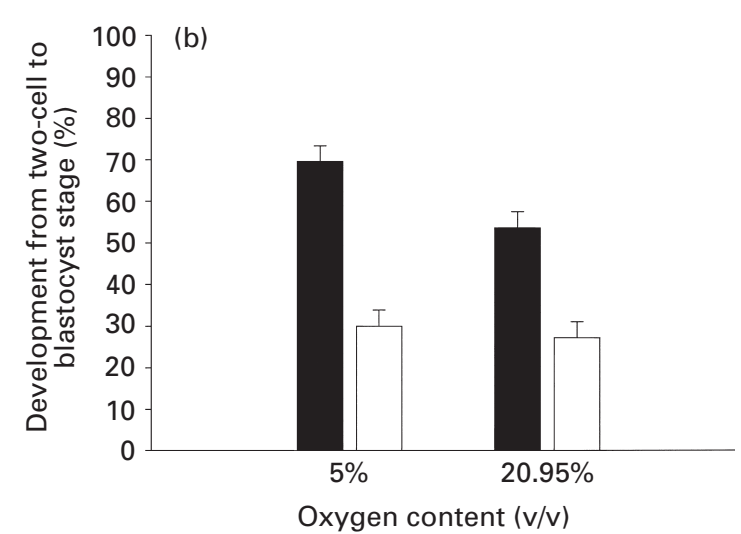

Fig. 4. Effect of culture conditions on responses of two-cell embryos to heat shock. (a) Effect of type of BSA used to supplement the culture medium on subsequent development to the blastocyst stage. Results are the percentage of two-cell embryos that became blastocysts on day 8 after insemination. The percentage of embryos becoming blastocysts was significantly different $(P<0.02)$ between embryos cultured at $38.5(\square)$ and $41.0^{\circ} \mathrm{C}(\square)$ for $12 \mathrm{~h}$ and between embryos cultured in media containing essentially fatty acid free (EFAF) BSA versus fraction $\mathrm{V}$ BSA $(P<0.01)$. However, there was no temperature $\times$ BSA type interaction. Data are least-squares means \pm SEM (mean of three replicates, each with 57-58 oocytes per treatment). (b) Effect of $\mathrm{O}_{2}$ concentration (5 or $20.95 \%$ ) during heat shock of two-cell embryos on subsequent development to the blastocyst stage. Results are the percentage of two-cell embryos that became blastocysts on day 8 after insemination. The percentage of embryos that developed into blastocysts was affected by incubation temperature $(P<0.01)$ and there was a tendency for $\mathrm{O}_{2}$ concentration to affect the percentage. Data are least squares means \pm SEM (mean of four replicates, each with 80-107 oocytes per treatment.

embryonic development is likely to be compromised by the direct actions of increased temperature on the oocyte and embryo. The finding that short-term heat shock ( $\leqslant 12$ h incubation) only affected development at very high temperatures $\left(41.0^{\circ} \mathrm{C}\right)$ may indicate that certain causes of heat-associated infertility associated with mild maternal hyperthermia are the result of effects other than the direct actions of increased temperature on embryonic survival.

Many previous reports have indicated the deleterious effects of increased temperature on oocytes and early em-
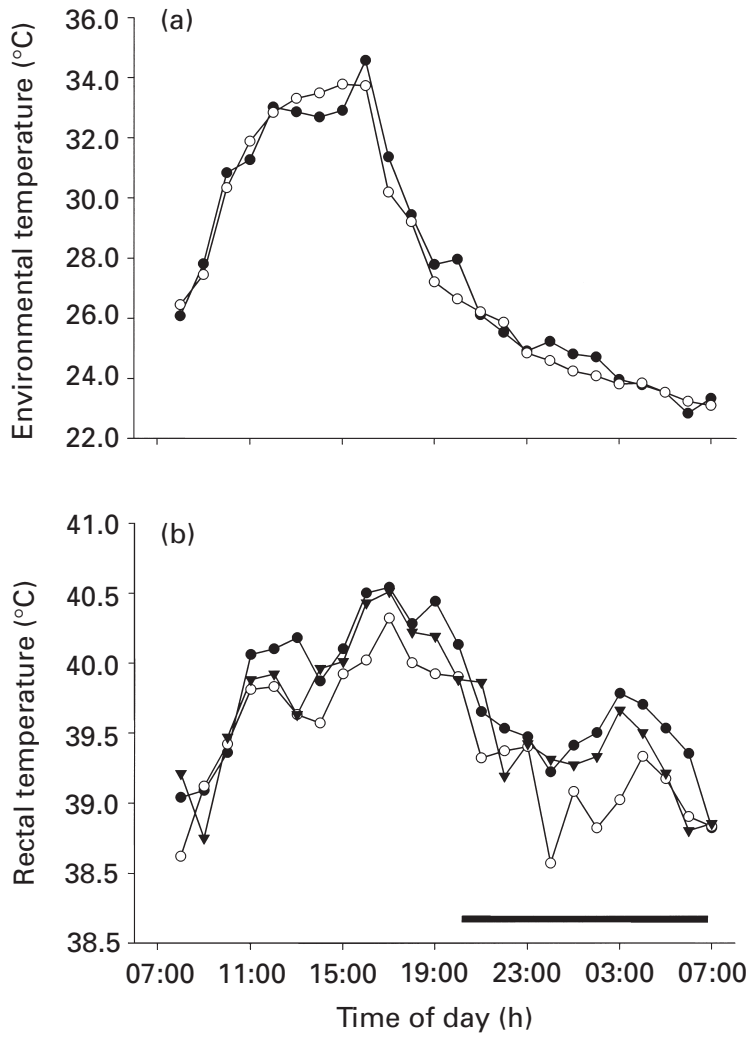

Fig. 5. Rectal temperatures of lactating dairy cows under heat stress conditions in North Florida. (a) Dry bulb (-) and black globe $(\bigcirc)$ environmental temperatures. (b) Rectal temperatures for cows that are predominantly black $(-n=9)$, about equally black and white $(\boldsymbol{\nabla} ; n=8)$ and predominantly white $(\bigcirc ; n=8)$. Rectal temperature was affected by coat colour $(P<0.001)$. Data are least square means. The pooled SEM in (b) is 0.19 . The black bar shows the period from sunset to sunrise.

bryos (Shah, 1956; Alliston and Ulberg, 1961; Dutt, 1963; Tompkins et al., 1967; Dunlap and Vicent, 1971; Turner, 1982). However, in these experiments, the effects of temperature were confounded with changes in $\mathrm{pH}$ because $\mathrm{CO}_{2}$ solubility in the medium decreases as temperature increases. In the present study, it is shown that, even when controlling for $\mathrm{pH}$ changes, decreased development occurs after exposure of oocytes, or one- or two-cell embryos to increased temperature. Moreover, this effect of heat shock is not simply an artefact caused by high oxygen concentrations in culture. Embryos are most commonly cultured in air, which has an $\mathrm{O}_{2}$ content of about 20.95\%, which is higher than that found in the oviduct or uterus $(<10 \%$; Fischer and Bavister, 1993). As formation of free radicals can increase as a result of exposure to high $\mathrm{O}_{2}$ tensions (Fowler and Callingham, 1978; Goto et al., 1993) and high temperatures (Flanagan et al., 1998), it is possible that the detrimental effects of heat shock in cultured embryos involves the formation of free radicals. In addition, heat shock of cultured embryos decreases concentrations of glutathione, which is a free radical scavenger (Aréchiga 

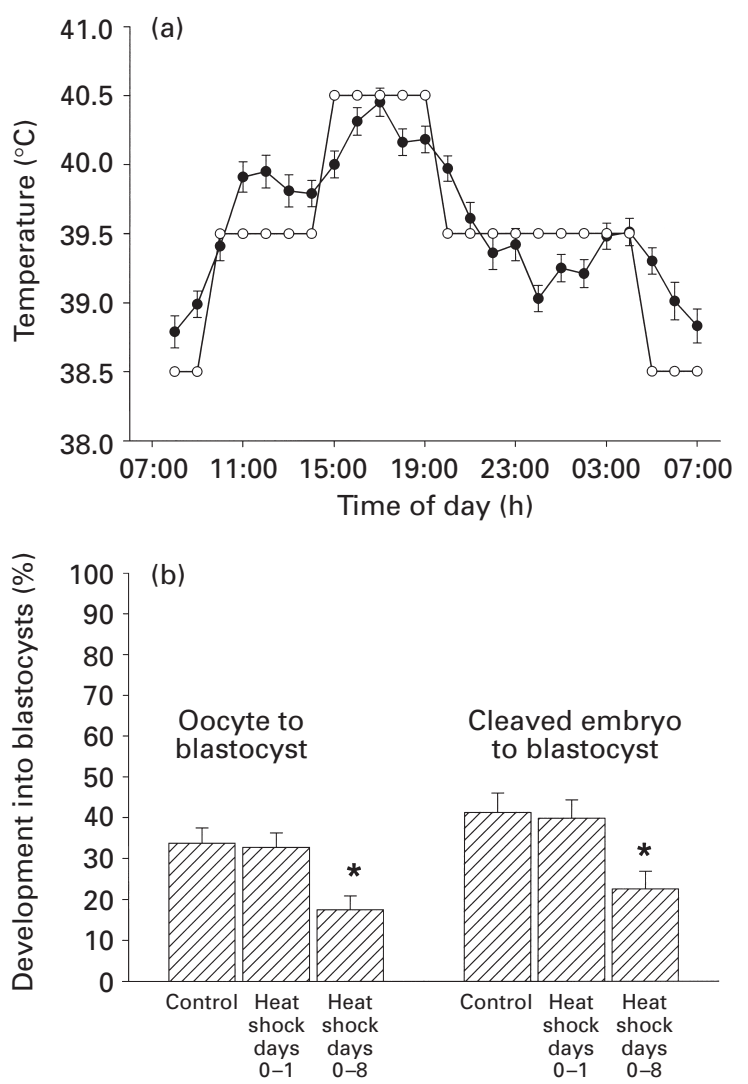

Fig. 6. Effect of exposing cultured embryos to a pattern of temperatures similar to that experienced by heat stressed cows. (a) Rectal temperatures of heat-stressed lactating dairy cows in North Florida (- least square means \pm SEM; $n=9)$ and culture temperatures for heat-shocked embryos $(\bigcirc)$. (b) Percentage of oocytes and percentage of cleaved embryos that developed into blastocysts after continuous exposure of embryos to $38.5^{\circ} \mathrm{C}$ (control), heat shock for $24 \mathrm{~h}$ starting $9 \mathrm{~h}$ after fertilization (heat shock days $0-1$ ) or heat shock throughout the culture period (heat shock days $0-8$ ). Data are least squares means \pm SEM (four replicates, each with 121-122 oocytes per treatment). *Significantly different from control $(P<0.05)$.

et al., 1995), and the adverse effects of heat on embryonic development can be minimized by various antioxidants (Ealy et al., 1992; Malayer et al., 1992; Aréchiga et al., 1994, 1995). Accordingly, in the present study, it was tested whether low $\mathrm{O}_{2}$ tension would reduce the detrimental effect of heat on two-cell embryos, presumably by lowering the exposure of the embryos to free radicals. There was no temperature by $\mathrm{O}_{2}$ interaction, which indicates that the deleterious effects of heat shock did not depend upon a high $\mathrm{O}_{2}$ environment.

It has been demonstrated that bovine embryos develop better when cultured in $5 \% \mathrm{O}_{2}$ than in air (Dumoulin et al., 1995; Takahashi et al., 1996; Fujitani et al., 1997; Lim et al., 1999). In the present study, a beneficial effect of low $\mathrm{O}_{2}$ was observed when embryos were exposed to low $\mathrm{O}_{2}$ for only $12 \mathrm{~h}$ at the two-cell stage of development. The modified media filters used in the present study offer a practical method for controlling oxygen concentration in embryo cultures to increase blastocyst yield.

The type of BSA used to supplement the culture medium also had an effect on development of embryos to the blastocyst stage. In particular, embryos developed better in media containing EFAF-BSA than in media containing fraction $\mathrm{V}$ BSA. However, the embryos that developed in EFAF-BSA were no more resistant to heat shock than were embryos that developed in fraction $\mathrm{V}$ BSA. The better development of embryos in EFAF-BSA could be due in part to the removal of fatty acids and other impurities from fraction $V$ BSA. The differences between development in media containing fraction $\mathrm{V}$ or EFAF BSA may also have reflected simple batch-to-batch variation (McKieman and Bavister, 1992) rather than any purification process-related effect.

In the experiment in which rectal temperatures of cows were determined, cows that were mostly white had lower rectal temperatures than did cows that were mostly black. This finding is in accordance with previous observations that white cows exposed to intense solar radiation have lower rectal and surface temperatures than do black cows (Hansen, 1990). In addition, King et al. (1988) reported that predominantly white cows that are mated in warm months had a shorter interval from calving to conception than did predominantly black cows. In contrast, Godfrey and Hansen (1996) failed to observe any effect of coat colour on reproduction of Holstein cows in the Caribbean.

In the present study, as has been reported previously (Ulberg and Burfening, 1967; Lenz et al., 1983), heat shock during fertilization reduced not only cleavage rate but also the ability of cleaved embryos to develop. Again, a high temperature $\left(41.0^{\circ} \mathrm{C}\right)$ was necessary to achieve this effect. The fact that exposure to $41.0^{\circ} \mathrm{C}$ affected fertilization rates may have been due in part to the effects of temperature on the oocyte (Lenz et al., 1983; Baumgartner and Chrisman, 1987; Edwards and Hansen, 1997; Rocha et al., 1998) or spermatozoa (Lenz et al., 1983; Chandolia et al., 1999). Heat shock could also affect syngamy or the first cleavage division. These processes involve microtubule and microfilament assembly (Kim et al., 1997), and cytoskeletal elements are known to collapse and aggregate after heat shock (Welch and Suhuan, 1985). Embryos formed from fertilization at $41.0^{\circ} \mathrm{C}$ had impaired developmental potential, perhaps because the damage to the cytoskeleton or other intracellular organelles persists. In addition, embryos formed via fertilization with heatdamaged spermatozoa had lower developmental potential (Ulberg and Burfening, 1967). Exposure of oocytes and spermatozoa to a temperature of $40.0^{\circ} \mathrm{C}$ during fertilization did not affect cleavage rate but did increase subsequent embryonic development. It is possible that $40.0^{\circ} \mathrm{C}$ was too low a temperature to damage gametes or embryos and that the increased thermal energy at $40.0^{\circ} \mathrm{C}$ increased the metabolic rate of the embryos.

The data obtained in the present study confirm that heat shocks such as those experienced by the cells of heat- 
stressed cows can compromise embryonic development. In vivo, heat-stressed cows typically experience daily fluctuations in body temperature that persist for many days. Results from the final experiment in the present study indicated that exposure of embryos to fluctuating temperatures similar to the rectal temperatures of cows experiencing heat stress could decrease embryonic development in vitro if the fluctuating temperatures occurred for several days. Thus, a longer more chronic heat shock may reduce embryo survival through the direct action of increased temperature on embryos. It is important to note that the temperatures chosen to perform this experiment were the mean rectal temperatures of cows experiencing heat stress, whereas uterine temperatures are typically about $0.2^{\circ} \mathrm{C}$ higher than rectal temperatures (Gwazdauskas et al., 1973). Thus, the actual temperatures experienced by embryos may be higher than those used in the present study.

Despite the fact that heat shock can disrupt embryonic development, a striking finding was that embryonic development was resistant to disruption by heat shocks of $39.5-40.5^{\circ} \mathrm{C}$ for up to $12 \mathrm{~h}$. Thus, it is possible that infertility associated with mild hyperthermia (Dunlap and Vincent, 1971) involves more chronic effects of heat shock exposure on embryos or is the result of other changes in oocyte, reproductive tract or embryonic function, independent of the direct effects of heat shock on embryos.

In conclusion, embryonic development can be disrupted by short-term ( 9 and $12 \mathrm{~h}$ ) heat shock applied during fertilization and at the one- and two-cell stages of development, but only when the heat shock is severe $\left(\geqslant 41.0^{\circ} \mathrm{C}\right)$. Furthermore, exposing embryos throughout the 8 days of culture in vitro to a pattern of temperatures similar to those experienced by heat-stressed lactating dairy cattle affects their development to the blastocyst stage. In addition, the effects of heat shock are not due to artefacts caused by changes in $\mathrm{pH}$ or high oxygen concentrations.

This is Journal Series No. R-07482 of the Florida Agricultural Experiment Station. The research was supported by USDA Grant 96-35205-3728 and the Florida Milk Checkoff Program. The authors thank C. Krininger, F. Paula-Lopes, Y. Al-Katanani, A. Majewski and $\mathrm{V}$. Bermudez for their assistance in the field and in the laboratory; K. Mohammed for collecting ovaries; A. Galarza for technical assistance; and S. Leibo (ACRES; New Orleans, LA) for technical advice concerning the relationship between $\mathrm{pH}$ and culture temperature. Special thanks are extended to M. Chernin and employees of Central Beef Packing Co (Center Hill, FL) for providing ovaries.

\section{References}

Alliston CW and Ulberg LC (1961) Early pregnancy loss in sheep at ambient temperatures of $70^{\circ}$ and $90^{\circ} \mathrm{F}$ as determined by embryo transfer Journal of Animal Science 20 608-613

Aréchiga CF, Ealy AD and Hansen PJ (1994) Efficacy of vitamin E and glutathione for thermoprotection of murine morulae Theriogenology 41 1545-1553
Aréchiga CF, Ealy AD and Hansen PJ (1995) Evidence that glutathione is involved in thermotolerance of preimplantation murine embryos Biology of Reproduction 52 1296-1301

Badinga L, Thatcher WW, Diaz T, Drost M and Wolfenson D (1993) Effect of environmental heat stress on follicular development and steroidogenesis in lactating Holstein cows Theriogenology 39 797-810

Baumgartner AP and Chrisman CL (1987) Embryonic mortality caused by maternal heat stress during mouse oocyte maturation Animal Reproduction Science 14 309-316

Chandolia RK, Reinertsen EM and Hansen PJ (1999) Lack of breed differences in response of bovine spermatozoa to heat shock Journal of Dairy Science 82 2617-2619

Dumoulin JC, Vanvuchelen RC, Land JA, Pieters MH, Geraedts JP and Evers JL (1995) Effect of oxygen concentration on in vitro fertilization and embryo culture in the human and the mouse Fertility and Sterility 63 115-119

Dunlap SE and Vincent CK (1971) Influence of postbreeding thermal stress on conception rate in beef cattle Journal of Animal Science 32 1216-1218

Dutt RH (1963) Critical period for early embryo mortality in ewes exposed to high ambient temperature Journal of Animal Science 22 713-719

Ealy AD and Hansen PJ (1994) Induced thermotolerance during early development of murine and bovine embryos Journal of Cell Physiology $160463-468$

Ealy AD, Drost M, Barros CM and Hansen PJ (1992) Thermoprotection of preimplantation bovine embryos from heat shock by glutathione and taurine Cell Biology International Report 16 125-131

Ealy AD, Drost M and Hansen PJ (1993) Developmental changes in embryonic resistance to adverse effects of maternal heat stress in cows Journal of Dairy Science 76 2899-2905

Edwards JL and Hansen PJ (1996) Elevated temperature increases heat shock protein 70 synthesis in bovine two-cell embryos and compromises function of maturing oocytes Biology of Reproduction $\mathbf{5 5}$ 340-346

Edwards JL and Hansen PJ (1997) Differential responses of bovine oocytes and preimplantation embryos to heat shock Molecular Reproduction and Development 46 138-145

Fischer B and Bavister BD (1993) Oxygen tension in the oviduct and uterus of rhesus monkeys, hamsters and rabbits Journal of Reproduction and Fertility 99 673-679

Flanagan SW, Moseley PL and Buettner GR (1998) Increased flux of free radicals in cells subjected to hyperthermia: detection by electron paramagnetic resonance spin trapping FEBS Letters 431 285-286

Fowler CJ and Callingham BA (1978) Substrate selective activation of rat liver mitochondrial monoamine oxidase by oxygen Biochemical Pharmacology 27 1995-2000

Fujitani Y, Kasai K, Ohtani S, Nishimura K, Yamada $M$ and Utsumi K (1997) Effect of oxygen concentration and free radicals on in vitro development of in vitro-produced bovine embryos Journal of Animal Science 75 483-489

Godfrey RW and Hansen PJ (1996) Reproduction and milk yield of Holstein cows in the US Virgin Islands as influenced by time of year and coat colour Archivos Latinoamericanos de Produccion Animal 4 31-44

Goto Y, Noda Y, Mori T and Nakano M (1993) Increased generation of reactive oxygen species in embryos cultured in vitro. Free Radical Biology and Medicine 15 69-75

Gwazdauskas FC, Thatcher WW and Wilcox CJ (1973) Physiological, environmental, and hormonal factors at insemination which may affect conception Journal of Dairy Science 56 873-877

Hansen PJ (1990) Effects of coat colour on physiological responses to solar radiation in Holsteins Veterinary Record 127 333-334

Kim NH, Chung KS and Day BN (1997) The distribution and requirements of microtubules and microfilaments during fertilization and parthenogenesis in pig oocytes Journal of Reproduction and Fertility $\mathbf{1 1 1}$ 143-149

King VL, Denise SK, Armstrong DV, Torabi M and Wiersma F (1988) Effects of a hot climate on the performance of first lactation Holstein cows grouped by coat colour Journal of Dairy Science 71 1093-1096 
Lenz RW, Ball GD, Leibfried ML, Ax RL and First NL (1983) In vitro maturation and fertilization of bovine oocytes are temperature-dependent processes Biology of Reproduction 29 173-179

Lim JM, Reggio BC, Godke RA and Hansel W (1999) Development of in-vitro-derived bovine embryos cultured in $5 \% \mathrm{CO}_{2}$ in air or in $5 \%$ $\mathrm{O}_{2}, 5 \% \mathrm{CO}_{2}$ and $90 \% \mathrm{~N}_{2}$ Human Reproduction 14 458-464

McKieman SH and Bavister BD (1992) Different lots of bovine serum albumin inhibit or stimulate in vitro development of hamster embryos In Vitro Cellular and Developmental Biology 28A 154-156

Malayer JR, Pollard JW and Hansen PJ (1992) Modulation by alanine and taurine of thermal killing of lymphocytes and preimplantation embryos American Journal of Veterinary Research 53 689-694

Parrish JJ, Susko-Parrish JL, Crister ES, Eyestone WH and First NL (1986) Bovine in vitro fertilization with frozen-thawed semen Theriogenology 25 591-600

Rocha A, Randel RD, Broussard JR, Lim JM, Blair RM, Roussel JD, Godke RA and Hansel W (1998) High environmental temperature and humidity decrease oocyte quality in Bos taurus but not in Bos indicus cows Theriogenology 49 657-665

Roman-Ponce H, Thatcher WW, Caton D and Wilcox CJ (1978) Thermal stress effects on uterine blood flow in dairy cows Journal of Animal Science 46 175-180

Roman-Ponce H, Thatcher WW and Wilcox CJ (1981) Hormonal interrelationships and physiological responses of lactating dairy cows to a shade management system in a subtropical environment Theriogenology 16 139-154

Rosenkrans CF, Zeng CQ, McNamara GT, Schoff PK and First NL (1993) Development of bovine embryos in vitro as affected by energy substrates Biology of Reproduction 49 459-462

Ryan DP, Blakewood EG, Lynn JW, Munyakazi L and Godke RA (1992) Effect of heat-stress on bovine embryo development in vitro. Journal of Animal Science 70 3490-3497

Ryan DP, Prichard, JF Kopel E and Godke RA (1993) Comparing early embryo mortality in dairy cows during hot and cool seasons of the year Theriogenology 39 719-737
SAS (1989) SAS User's Guide. Version 6. Statistical Analysis System Institute Inc, Cary, NC

Shah MK (1956) Reciprocal egg transplantations to study the embryouterine relationship in heat-induced failure of pregnancy in rabbits Nature 177 1134-1135

Takahashi Y, Hishinuma M, Tanaka H and Kanagawa H (1996) Development of in vitro matured/fertilisation bovine embryos in a chemically defined medium: influence of oxygen concentration in the gas atmosphere Journal of Veterinary Medical Sciences 58 897-902

Tompkins EC, Heidenreich CJ and Stob M (1967) Effects of post-breeding thermal stress on embryonic mortality of swine Journal of Animal Science 26 377-380

Trout JP, McDowell LR and Hansen PJ (1998) Characteristics of the estrous cycle and antioxidant status of lactating Holstein cows exposed to heat stress Journal of Dairy Science 81 1244-1250

Turner HG (1982) Genetic variation of rectal temperature in cows and its relationship to fertility Animal Production 35 401-412

Ulberg LC and Burfening PJ (1967) Embryo death resulting from adverse environment on spermatozoa or ova Journal of Animal Science 26 571-577

Ulberg LC and Sheean LA (1973) Early development of mammalian embryos in elevated ambient temperatures Journal of Reproduction and Fertility Supplement 19 155-161

Welch WJ and Suhuan JP (1985) Morphological study of the mammalian stress response: characterization of changes in cytoplasmic organelles, cytoskeleton, and nucleoli, and appearance of intranuclear actin filaments in rat fibroblasts after heat shock treatment Journal of Cell Biology 101 1198-1211

Wolfenson D, Thatcher WW, Badinga L, Savio JD, Meidan R, Lew BJ, Braw-Tal R and Berman A (1995) Effect of heat stress on follicular development during the estrous cycle in lactating dairy cattle Biology of Reproduction 52 1106-1113

Received 23 May 2000

Accepted 7 August 2000. 